\title{
Abnormalities of T Cell Maturation and Regulation in Human Beings with Immunodeficiency Disorders
}

\author{
Ellis L. Reinherz, Max D. Cooper, Stuart F. Schlossman, \\ and Fred S. Rosen, Division of Tumor Immunology, Sidney Farber Cancer \\ Institute, Department of Medicine, Harvard Medical School, \\ Division of Immunology, Children's Hospital Medical Center, \\ Department of Pediatrics, Boston, Massachusetts 02115; Cellular \\ Immunobiology Unit of the Lurleen B. Wallace Tumor Institute, Department \\ of Pediatrics and Microbiology, University of Alabama, \\ Birmingham, Alabama 35294
}

A B S T R A C T A series of monoclonal antibodies to T cell surface antigens were used to characterize peripheral lymphoid populations from patients with a variety of immunodeficiency diseases. Several disorders of $\mathrm{T}$ cell differentiation were observed to occur in severe combined immunodeficiency. One subtype of severe combined immunodeficiency was associated with failure to develop lymphocytes that express any thymus specific antigens, another with failure to differentiate beyond the early prothymocyte-thymocyte $\left(\mathrm{T}^{+}, \mathrm{T} 0^{+}\right)$stage, while a third subtype was associated with failure to differentiate beyond a late thymocyte $\left(\mathrm{T}^{+}, \mathrm{T}^{+}, \mathrm{T}^{+} / \mathrm{T} 8^{+}, \mathrm{T} 10^{+}\right)$stage. In contrast, patients with thymic aplasia (DiGeorge syndrome) had a diminished but detectable population of mature $\mathrm{T}$ cells. Imbalances in immunoregulatory $\mathrm{T}$ cells with a relative excess of suppressor cells were found in 9 of 17 patients with spontaneously occurring acquired agammaglobulinemia. In one of the latter individuals, there was an activated suppressor $\mathrm{T}$ cell population expressing $\mathrm{Ia}$ antigens $\left(\mathrm{T}^{+} / \mathrm{T}^{+}, \mathrm{Ia}^{+}\right)$. Another had no inducer $\mathrm{T}^{+}$cells. Patients with $\mathrm{X}$-linked agammaglobulinemia frequently had an abnormal ratio of inducer to suppressor cells as well as an absence of circulating surface immunoglobulin-bearing cells. No such abnormalities were noted in normals or individuals with selective immunoglobulin (Ig)A deficiency. Taken together, these findings support the notion that several immunodeficiency states may occur as a consequence of defective $T$ cell maturation or imbalances in immunoregulatory $\mathrm{T}$ lymphocyte subpopulations.

Received for publication 23 February 1981 and in revised form 17 April 1981.

\section{INTRODUCTION}

The human immune system, like the murine system, consists of discrete subsets of $\mathrm{T}$ lymphocytes which are critical for immune homeostasis (1-2). Numerous studies have now demonstrated that it is the balance between effector and regulatory subsets of cells that actually governs the outcome of an immunologic response after antigen triggering. The $\mathrm{T}$ inducer/ helper subset facilitates the activation of other cells, including $\mathrm{T}$ lymphocytes, B lymphocytes, macrophages, and hematopoietic stem cells $(1,3-6)$. This inductive influence is regulated by the presence of suppressor $\mathrm{T}$ lymphocytes, which function to either inactivate the inducer population, or, alternatively, the effector population (6-7).

Prior studies have indicated that during intrathymic differentiation and maturation, $T$ cells diverge into functionally distinct subpopulations of cells programmed for their respective inducer/helper and cytotoxic/ suppressor functions (8). In man, the earliest cells within the thymus bear antigens shared by some bone marrow cells but lacking on mature $T$ lymphocytes. This population (stage I thymocytes) accounts for $\sim 10 \%$ of the total thymic population and is reactive with two monoclonal antibodies, anti-T9 and anti-T10. With maturation, thymocytes lose $\mathrm{T} 9$, retain $\mathrm{T} 10$, and acquire a thymocyte-distinct antigen, T6, analogous to the TL antigen in the mouse. Concurrently, these cells express antigens defined by anti-T4 and anti$\mathrm{T} 5 / 8$. Thus, the $\mathrm{T}^{+}, \mathrm{T} 5 / 8^{+}, \mathrm{T}^{+}, \mathrm{T} 10^{+}$thymic population (stage II common thymocytes) accounts for $70-80 \%$ of the total. Stage I and II thymocytes are immunologically incompetent. With further maturation, thymocytes lose the $\mathrm{T} 6$ antigen, acquire $\mathrm{T} 3$, and segregate into distinct $\mathrm{T}^{+}$and $\mathrm{T}^{+} / 8^{+}$subsets (stage 
III thymocytes). Immunologic competence is partially acquired at this stage, but not fully developed until the thymic population is exported, at which time the T10 antigen is lost (9). The mature circulating $\mathrm{T}^{+}$, $\mathrm{T} 4^{+}$population and $\mathrm{T} 3^{+}, \mathrm{T} 5 / 8^{+}$population are reciprocal subsets of cells and account for $55-65 \%$ and $30 \%$ of the $\mathrm{T}$ cell population, respectively (1). These subsets, in addition to their effector function, exert profound regulatory effects and control both the type and intensity of the cellular immune response. Thus, only the $\mathrm{T}^{+} \mathrm{T}$ cell-induced cytotoxic $\mathrm{T}$ killer cells (3), facilitated $\mathrm{B}$ cell proliferation, differentiation, and immunoglobulin production (4), and generated soluble helper factors $(5)$. In contrast, the $\mathrm{T} 5 / 8^{+}$population became the cytotoxic/effector cell in cell-mediated lympholysis (7), was inducible by concanavalin $\mathrm{A}$ to suppress $T$ cell responses (7), and suppressed B cell immunoglobulin production (6).

Many investigators have reported on aberrations of $T$ cell subsets in immunodeficiency diseases (10-12). In the present study, we have examined the differentiation of populations of $\mathrm{T}$ lymphocytes in a group of patients with acquired and congenital immunodeficiencies using monoclonal antibodies to mark stages of $\mathrm{T}$ cell maturation and to discriminate functionally distinct subsets. Our results support the notion that immunologic incompetence can result from two types of disorders of $\mathrm{T}$ cell development. Firstly, there exist disorders associated with release of immature thymocytes into the circulation. On the other hand, immunoincompetence may also result from disorders in which there is either a marked reduction or imbalance in mature $\mathrm{T}$ lymphocytes with associated abnormalities in inducer/suppressor cell ratios and function.

\section{METHODS}

Patient population. The diagnosis of severe combined immunodeficiency (SCID), ${ }^{1}$ thymic aplasia (DiGeorge syndrome), acquired and X-linked forms of agammaglobulinemia, and IgA deficiency were defined by previously reported criteria (13). All patients with SCID were adenosine deaminase positive $\left(\mathrm{ADA}^{+}\right)$. Normal control blood was obtained from healthy individuals undergoing other routine laboratory procedures. No patients were acutely ill or receiving steroid therapy at the time of study.

Mononuclear cell preparation. Mononuclear cells were prepared by Ficoll-Hypaque (Pharmacia Fine Chemicals, Div. Pharmacia, Inc., Piscataway, N. J.) density centrifugation as previously described (9).

Monoclonal antibodies. A series of monoclonal antibodies was used to define cell surface antigens on human lymphocytes of $\mathrm{T}$ lineage. Their production and characterization has been described in detail previously. In brief, anti-T3 was found to be reactive with all peripheral $T$ cells and a

\footnotetext{
${ }^{1}$ Abbreviations used in this paper: MLC, mixed lymphocyte culture; SCID, severe combined immunodeficiency.
}

fraction of mature thymocytes (14). In contrast, anti-T4 and anti-T5/8 reacted with subpopulations of $T$ cells representing 60 and $20-30 \%$ of peripheral $\mathrm{T}$ cell populations, respectively $(3,7-8)$. The former population defined the human inducer subset, whereas the latter two antibodies defined the cytotoxic/suppressor subset. Anti-T6 defined a thymus specific antigen expressed on $70 \%$ of thymocytes and lacking on peripheral lymphocytes of $\mathrm{T}$ or non-T lineage (8). Anti-T9 reacted with an antigen expressed on $10 \%$ of thymocytes, but not on resting normal $\mathrm{T}$ cells or non-T cells in lymphoid organs. The anti-T10 monoclonal antibody was reactive with $\geq 95 \%$ of thymocytes, $\leq 20 \%$ of bone marrow cells, and $\leq 10 \%$ of peripheral $\mathrm{T}$ cells (8). Finally, the anti-Ia monoclonal antibody defined a bimolecular glycoprotein antigen complex of 29,000- and 34,000-dalton subunits and was reactive with resting $B$ cells and a fraction of monocytes, but unreactive with resting $T$ cells. This antigen was found to be expressed, moreover, on $\mathrm{T}$ cells after activation (14).

Analysis of lymphocyte populations in patients with immunodeficiency. After separation by density centrifugation, $1-2 \times 10^{6}$ lymphocytes were incubated at $4^{\circ} \mathrm{C}$ for $30 \mathrm{~min}$ in a 1:250 dilution of one or another monoclonal antibody and then washed twice. The cells were subsequently reacted with a 1:40 dilution of goat anti-mouse IgG $(\mathrm{G} / \mathrm{M}$ FITC) (Meloy Laboratories, Springfield, Va.) or with mouse IgG subclass specific goat antibodies for $30 \mathrm{~min}$, centrifuged, washed three times, and analyzed on a FACS (FACS-I) (Becton-Dickinson, Mountain View, Calif.), Zeiss (Carl Zeiss, Inc., New York) or Leitz (E. Leitz, Inc., Rockleigh, N. J.) immunofluorescent microscope, or both, as previously described $(3-4,15)$. Background staining was obtained by substituting $0.15 \mathrm{ml}$ of a 1:250 dilution of control ascites from a mouse immunized with a nonproducing hybridoma clone. Results of cell reactivity obtained by FACS or immunofluorescent scope analysis varied $<10 \%$ from one another. For determination of surface $(\mathrm{s}) \mathrm{IgM}^{+}$cells, an identical procedure was utilized, with the exception that an $\mathbf{F}\left(\mathbf{a b}^{\prime}\right)_{2}$ rabbit anti-human IgM-FITC (N. L. Cappel Laboratories, Cochranville, $\mathrm{Pa}$.) or an affinity purified goat antihuman IgM-FITC was substituted for G/M FITC.

Mixed lymphocyte culture. The proliferative responses to alloantigens in mixed lymphocyte culture (MLC) were measured by tritiated thymidine $\left(\left[{ }^{3} \mathrm{H}\right] \mathrm{TdR}\right)$ incorporation as previously described, utilizing $10^{5}$ responder lymphocytes and $10^{5}$ mitomycin $c$ treated stimulator cells (3).

\section{RESULTS}

SCID: heterogeneity of defects in T cell maturation. SCID denotes a heterogeneous group of hereditary diseases in which there is a failure of normal $\mathrm{T}$ and B cell maturation (16). Peripheral blood lymphocytes were analyzed from five of these patients. As shown in Table $I$, three major patterns of reactivity with anti-T cell monoclonal antibodies were observed. Patients 1-3 lacked any circulating cells bearing mature $\mathrm{T}$ cell antigens. $12 \%$ of lymphocytes from patient 1 bore the T10 antigen found on bone marrow precursor cells (presumably including prothymocytes) and thymocytes, but no antigens normally acquired in the thymus. Although patients 2 and 3 lacked T cells of mature phenotype, unlike patient 1 , a sizeable portion of their circulating lymphocytes bore both $\mathrm{T} 9$ and T10 antigens, characteristic of stage I thymocytes. 
TABLE I

Analysis of Circulating Lymphocytes from Patients with SCID

\begin{tabular}{|c|c|c|c|c|c|c|c|c|c|c|c|}
\hline \multirow[b]{2}{*}{ Patient } & \multirow[b]{2}{*}{ Age } & \multirow[b]{2}{*}{ Sex } & \multirow[b]{2}{*}{ Leukocytes $/ \mathrm{mm}^{3}$} & \multirow[b]{2}{*}{ \% Lymphocytes } & \multicolumn{6}{|c|}{ \% Reactivity with monoclonal antibodies anti } & \multirow{2}{*}{$\begin{array}{c}\text { MLC } \\
\text { proliferation }\end{array}$} \\
\hline & & & & & $-\mathrm{T} 3$ & $-\mathrm{T} 4$ & $-\mathrm{T} 6$ & $-\mathrm{T} 8$ & $-\mathrm{T} 9$ & $-\mathrm{T} 10^{*}$ & \\
\hline 1 & $5 \mathrm{mo}$ & $\mathbf{M}$ & 4,200 & 20 & $\mathbf{0}$ & 0 & 0 & $\mathbf{0}$ & 0 & 12 & $<3$ \\
\hline 2 & $3 \mathrm{mo}$ & $\mathbf{F}$ & 5,300 & 14 & $\mathbf{0}$ & 0 & 0 & 0 & 50 & 55 & $<3$ \\
\hline 3 & $10 \mathrm{mo}$ & $\mathbf{M}$ & 5,700 & 55 & 0 & 0 & 0 & 0 & 33 & 30 & $<3$ \\
\hline 4 & $6 \mathrm{mo}$ & $\mathbf{F}$ & 6,851 & 68 & 65 & 69 & 0 & 60 & 2 & 63 & 43 \\
\hline 5 & $4 \mathrm{yr}$ & $\mathbf{F}$ & 8,155 & 26 & 76 & 82 & 0 & 68 & 0 & 60 & 27 \\
\hline
\end{tabular}

* Normal age-matched values $(n=5)$ : anti-T3 $=71 \pm 5$; anti-T4 $=45 \pm 4$; anti-T6 $=0$; anti-T $=22 \pm 3$; anti-T9 $=1 \pm 1$; and anti-T10 $=10 \pm 8$. (Results are expressed as mean \pm SEM.)

$\ddagger$ MLC proliferation is expressed as stimulation index = experimental counts/media control counts.

It should be noted that lymphocytes from patients 1-3 lacked all $\mathrm{T}$ cell functions tested, including soluble and alloantigen proliferation, mitogen proliferation, and cytotoxic effector cell generation in cell mediated lympholysis (data not shown). Moreover, these individuals were severely hypoglobulinemic as well $(<100 \mathrm{mg} / \mathrm{dl}$ of IgG and undetectable IgA and IgM). In contrast, patients 4 and 5 maintained a circulating $\mathrm{T}$ cell population that expressed $\mathrm{T} 3$ antigen. Both of the latter patients' $T$ cells co-expressed T3, $\mathrm{T} 4, \mathrm{~T} 8$, and T10 antigens. This phenotype is characteristic of stage III thymocytes.

Further evidence for the distinctions between SCID patients 1-3 and patients 4 and 5 was a functional observation that the latters' $T$ cells proliferated to alloantigens in MLC, whereas the former's did not (Table I). However, lymphocytes from all patients lacked proliferative responses to any dose of phytohemagglutinin tested or the specific antigens, tetanus toxoid or diptheria toxoid under optimal culture concentrations $(10 \mu \mathrm{g} / \mathrm{ml})$ and despite prior sensitization.

DiGeorge syndrome. Congenital thymic aplasia (DiGeorge syndrome) results from failure of embryogenesis of the entodermal derivatives of the third and fourth pharyngeal pouches $(17,18)$. The accompanying $T$ cell defect is associated with susceptibility to viral, fungal, and bacterial infections on the one hand, and an increased incidence of autoimmunity in later years on the other (19).

Analysis of lymphocytes from five patients demonstrated a significantly decreased percentage of $\mathrm{T}^{+}$ mature $T$ cells in four of five cases (patients $1,3,4$ and 5; Table II). No $\mathrm{T}^{+}$cells were noted and the percentage of $\mathrm{T}^{+}$and $\mathrm{T}^{+} 0^{+}$cells was normal (data not shown). Perhaps more importantly, there was a decrease in percentage of $\mathrm{T}^{+}$suppressor/cytotoxic cells relative to $\mathrm{T}^{+}{ }^{+}$inducer cells (high $\mathrm{T}^{+}: \mathrm{T} 8^{+}$ratio) in all five cases.

X-linked and common varied forms of agammaglobulinemia and selective IgA immunodeficiency. To determine whether there were abnormalities of inducer/suppressor ratios in other immunodeficiency states, $T$ cell subsets were characterized in patients with common varied or "late onset" agammaglobulinemia, X-linked agammaglobulinemia, and selective IgA immunodeficiency. We studied the distribution of peripheral $T$ cell subsets in 17 patients with late onset agammaglobulinemia, most of whom possessed normal numbers of $B$ cells. A relative increase in $\mathrm{T}^{+}$cells was observed in 9 of those $17 \mathrm{pa}-$ tients (Table III). One individual, patient 13 , not only had a marked increase in the T5 population but these

TABLE II

T Cell Subsets in Patients with Congenital Thymic Aplasia (DiGeorge Syndrome)

\begin{tabular}{|c|c|c|c|c|c|c|c|c|c|}
\hline \multirow[b]{2}{*}{ Patient } & \multirow[b]{2}{*}{ Age } & \multirow[b]{2}{*}{ Sex } & \multirow[b]{2}{*}{ Leukocytes $/ \mathrm{mm}^{3}$} & \multirow[b]{2}{*}{ \% Lymphocytes } & \multicolumn{4}{|c|}{$\%$ Reactivity with monoclonal antibodies anti } & \multirow[b]{2}{*}{ Ratio T4:T8t } \\
\hline & & & & & $-\mathbf{T} 3$ & $-\mathrm{T} 4$ & $-\mathrm{T} 6$ & $-\mathrm{T} 8^{*}$ & \\
\hline 1 & $4 \mathrm{mo}$ & $\mathbf{F}$ & 9,700 & 30 & 27 & 23 & 0 & 4 & 5.8 \\
\hline 2 & $2 \mathrm{mo}$ & $\mathbf{M}$ & 13,200 & 24 & 64 & 59 & 0 & 14 & 4.2 \\
\hline 3 & $8 \mathrm{yr}$ & $\mathbf{M}$ & 8,700 & 35 & 35 & 31 & 0 & 7 & 4.4 \\
\hline 4 & $6 \mathrm{yr}$ & $\mathbf{M}$ & 11,300 & 28 & 18 & 14 & 0 & 2 & 7 \\
\hline 5 & $36 \mathrm{yr}$ & $\mathbf{F}$ & 8,700 & 18 & 14 & 9 & 0 & 2 & 4.5 \\
\hline
\end{tabular}

* Normal childhood and adult age values for 25 controls: anti-T3 = 68 \pm 4 ; anti-T4 = 39 \pm 3 ; anti-T6 =0; and anti-T8 = 24 \pm 1 . \$ Normal T4:T8 ratio $=1.9 \pm 0.3$ for 25 controls. 
TABLE III

T Cell Subsets in Patients with Common Variable Agammaglobulinemia and a Circulating B Cell Population

\begin{tabular}{|c|c|c|c|c|c|c|c|c|c|c|}
\hline \multirow[b]{2}{*}{ Patient } & \multirow[b]{2}{*}{ Age } & \multirow[b]{2}{*}{ Sex } & \multirow[b]{2}{*}{ Leukocytes $/ \mathrm{mm}^{3}$} & \multirow[b]{2}{*}{ \% Lymphocytes } & \multicolumn{4}{|c|}{ \% Reactivity with monoclonal antibodies anti } & \multirow{2}{*}{$\frac{\% \text { Cells }}{\text { sIgM }^{+} t}$} & \multirow[b]{2}{*}{ T4:T5 Ratio* } \\
\hline & & & & & $-\mathrm{T} 3$ & $-\mathrm{T} 4$ & $-\mathrm{T} 5$ & $-I a$ & & \\
\hline 1 & 55 & $\mathbf{M}$ & 9,100 & 15 & 59 & 29 & 34 & 20 & 10.5 & 0.85 \\
\hline 2 & 36 & $\mathbf{F}$ & 8,000 & 20 & 65 & 21 & 37 & 18 & 10.5 & 0.57 \\
\hline 3 & 38 & $\mathbf{F}$ & 4,100 & 40 & 65 & 28 & 30 & 20 & 7 & 0.93 \\
\hline 4 & 23 & $\mathbf{F}$ & 9,700 & 27 & 73 & 43 & 20 & 13 & 10 & 2.15 \\
\hline 5 & 33 & $\mathbf{M}$ & 5,200 & 48 & 78 & 28 & 41 & 28 & 15.8 & 1.46 \\
\hline 6 & 25 & $\mathbf{F}$ & 3,600 & 23 & 67 & 32 & 28 & - & 5.8 & 1.14 \\
\hline 7 & 20 & $\mathbf{F}$ & 9,700 & 32 & 78 & 41 & 27 & - & 13.1 & 1.52 \\
\hline 8 & 43 & $\mathbf{F}$ & 6,900 & 38 & 58 & 10 & 48 & - & 3.7 & 0.21 \\
\hline 9 & 45 & $\mathbf{F}$ & - & - & 60 & 30 & 27 & 25 & 6.2 & 0.11 \\
\hline 10 & 22 & $\mathbf{M}$ & - & - & 50 & 31 & 15 & 7 & 4.5 & 2.07 \\
\hline 11 & 11 & $\mathbf{M}$ & 10,200 & 7 & 70 & 13 & 28 & 5 & 9 & 0.46 \\
\hline 12 & 16 & $\mathbf{M}$ & 20,100 & 11 & 30 & 26 & 10 & - & 7 & 2.6 \\
\hline 13 & 17 & $\mathbf{M}$ & 13,500 & 52 & 80 & 15 & 68 & 70 & 6 & 0.22 \\
\hline 14 & 10 & $\mathbf{F}$ & 4,500 & 36 & 75 & 0 & 72 & 12 & 10 & 0 \\
\hline 15 & 15 & $\mathbf{M}$ & 7,100 & 53 & 49 & 30 & 12 & 15 & 8.6 & 2.5 \\
\hline 16 & 21 & $\mathbf{F}$ & 6,200 & 46 & 64 & 46 & 20 & 15 & 9 & 2.30 \\
\hline 17 & 15 & $\mathbf{M}$ & - & - & 33 & 20 & 14 & 13 & 8 & 1.43 \\
\hline
\end{tabular}

* Normal ratio $2.0 \pm 0.3$ for 25 normal controls.

$\ddagger$ Cells sIgM in normals $=9 \pm 2$.

cells were activated as judged by the coexpression of Ia antigen. This individual's $\mathrm{T}^{+}$subset was previously shown to suppress a normal HLA-identical brother's B cells from secreting immunoglobulin (12).

A novel phenotype was defined in patient 14: all of her circulating $\mathrm{T}$ cells expressed the $\mathrm{T} 5$ antigen and none were $\mathrm{T}^{+}$. The patient's $\mathrm{T}$ cells failed to provide helper function to initiate $B$ cell immunoglobulin secretion and, unlike the $\mathrm{T}$ lymphocytes from patient 13, were Ia negative and had no suppressor effect.

Table IV shows the results of $T$ cell subset analysis of patients with $\mathrm{X}$-linked agammaglobulinemia who lack surface immunoglobulin positive B cells. The majority of patients with this disorder did not possess a low ratio of inducer/suppressor cells (7 of 11). However, only 3 of 11 patients had a normal ratio; 4 of 11 were found to have a relative increase in their inducer/ suppressor ratio (patients $3,4,6$, and 7 ), whereas others had a relative decrease (patients $1,2,10$, and 11). That these abnormalities of $\mathrm{T}$ cell subsets are not accompanying findings in all immunodeficiency state is clear from analysis of $T$ cell subsets in patients with selective IgA deficiency. Individuals with this syndrome had no abnormalities in $\mathrm{T}$ cell subsets (Table V).

TABLE IV

TCell Subsets in Males with X-Linked Agammaglobulinemia and No Surface Immunoglobulin-Bearing B Cells

\begin{tabular}{|c|c|c|c|c|c|c|c|c|}
\hline \multirow[b]{2}{*}{ Patient } & \multirow[b]{2}{*}{ Age } & \multirow[b]{2}{*}{ Leukocytes $/ \mathrm{mm}^{3}$} & \multirow[b]{2}{*}{ \% Lymphocytes } & \multicolumn{4}{|c|}{ \% Reactivity with monoclonal antibodies anti } & \multirow[b]{2}{*}{ T4:T5 Ratio } \\
\hline & & & & $-\mathbf{T} 3$ & $-\mathrm{T} 4$ & $-\mathrm{T5}$ & $-\mathbf{I a}$ & \\
\hline 1 & 16 & 10,000 & 40 & 75 & 34 & 55 & 22 & 0.62 \\
\hline 2 & 19 & 7,500 & 43 & 78 & 41 & 37 & 27 & 1.11 \\
\hline 3 & 14 & 9,900 & 29 & 84 & 56 & 17 & 20 & 3.29 \\
\hline 4 & 12 & 5,700 & 48 & 71 & 44 & 13 & 30 & 3.38 \\
\hline 5 & 3 & 9,900 & 30 & 66 & 40 & 25 & 15 & 1.60 \\
\hline 6 & 15 & 8,700 & 31 & 64 & 37 & 13 & - & 2.85 \\
\hline 7 & 1 & 6,000 & 85 & 76 & 62 & 13 & - & 4.77 \\
\hline 8 & 26 & 9,800 & 30 & 65 & 53 & 20 & 31 & 2.65 \\
\hline 9 & 17 & 7,600 & 20 & 30 & 20 & 10 & 25 & 2.0 \\
\hline 10 & 25 & 14,300 & 13 & 50 & 16 & 25 & 21 & 0.64 \\
\hline 11 & 5 & 5,000 & 70 & 30 & 14 & 19 & 29 & 0.79 \\
\hline
\end{tabular}


TABLE V

Analysis of Lymphocytes in Patients with Selective IgA Deficiency

\begin{tabular}{|c|c|c|c|c|c|c|c|c|}
\hline \multirow[b]{2}{*}{ Patient } & \multirow[b]{2}{*}{ Age } & \multirow[b]{2}{*}{ Sex } & \multirow[b]{2}{*}{ Leukocytes } & \multirow[b]{2}{*}{ \% Lymphocytes } & \multicolumn{4}{|c|}{ \% Reactivity with monoclonal antibodies anti } \\
\hline & & & & & $-\mathrm{T} 3$ & $-\mathrm{T} 4$ & $-\mathrm{T} 5$ & $-\mathrm{Ia}$ \\
\hline 1 & 6 & $\mathbf{F}$ & 14,500 & 17 & 62 & 28 & 17 & 22 \\
\hline 2 & 17 & $\mathbf{M}$ & 4,400 & 27 & 61 & 44 & 17 & 40 \\
\hline 3 & 47 & $\mathbf{M}$ & 6,200 & 23 & 60 & 46 & 9 & 34 \\
\hline 4 & 4 & $\mathbf{M}$ & - & - & 49 & 28 & 13 & 31 \\
\hline 5 & 50 & $\mathbf{F}$ & 4,600 & 46 & 69 & 34 & 23 & 24 \\
\hline 6 & 30 & $F$ & 6,000 & 24 & 60 & 39 & 15 & 24 \\
\hline 7 & 28 & $\mathbf{F}$ & - & - & 44 & 25 & 17 & - \\
\hline 8 & 21 & $\mathbf{M}$ & 11,100 & 11 & 65 & 33 & 28 & - \\
\hline 9 & 14 & $\mathbf{M}$ & 7,800 & 25 & 57 & 33 & 23 & - \\
\hline
\end{tabular}

\section{DISCUSSION}

In the present study, lymphocytes from patients with a variety of immunodeficiency states were characterized utilizing a series of monoclonal antibodies. In a large number of patients, abnormalities of $T$ cell differentiation as well as imbalances in mature immunoregulatory $\mathrm{T}$ cell subsets were observed. As an example of the former, examination of the circulating mononuclear cells in patients with SCID revealed three major phenotypes. One SCID patient had lymphocytes bearing the early bone marrow and/or thymocyte antigen T10 exclusively. This individual, lacking in lymphocytes expressing antigens normally acquired in the thymus, was the only one in our series to meet the criteria of the Swiss type SCID (13). In addition, a second group of patients had lymphocytes bearing both T9 and T10 antigens while a third group had circulating lymphocytes which were arrested at the level of stage III in thymocyte development and thus bore the T3, T4, T5/T8, and T10 antigens. We were unable to detect SCID patients with defects of differentiation resulting in circulating stage II $\left(\mathrm{T}^{+}\right)$thymocytes. This might have been due to the small patient population tested, or alternatively, the possibility that normal thymocytes of this phenotype are incapable of migrating to peripheral blood.

Patients with DiGeorge syndrome and acquired agammaglobulinemia often had abnormalities of mature $T$ cell subset distribution. In the case of DiGeorge syndrome, all patients studied had a diminution of $\mathrm{T}^{+}$suppressor cells as judged by an elevated ratio of $\mathrm{T}^{+}{ }^{+}$inducer/ $/ 8^{+}$suppressor cells. In contrast, 9 of the 17 patients with acquired agammaglobulinemia had a relative excess of suppressor cells and a reduced inducer/suppressor ratio. The latter findings would indicate that excess of suppressor cells may not be an infrequent cause of acquired agammaglobulinemia. The distribution of $T$ cell subsets in patients with $\mathrm{X}$ linked agammaglobulinemia who had no circulating
B cells was often abnormal as well but was characterized by either a decrease or increase in the inducer/ suppressor ratio. Thus, there was no predominant pattern. No abnormality in $\mathrm{T}$ cell subsets was associated with selective IgA deficiency.

The observation that three major phenotypic forms of SCID appear to exist is consistent with a variety of functional data implying heterogeneity in this disease category (16). Thus, one group of SCID patients with circulating stage III thymocytes mounted a normal proliferative response to alloantigens and had relatively normal immunoglobulin levels (Table I, unpublished data). Since it was previously shown that the capacity to proliferate to alloantigens in MLC was developed at the time of acquisition of mature $T$ cell antigens (i.e., T3), these results were not unexpected (9). In contrast to those individuals, SCID patients with $\mathrm{T} 10$ or $\mathrm{T} 9$ and $\mathrm{T}^{+} 0^{+}$lymphocytes were immunoincompetent and this would appear to correlate with the relative immaturity of this lymphoid population. In these individuals, $<5 \%$ of their mononuclear population rosetted with sheep erythrocyte (data not shown). In addition, it is of note that one group of SCID patients has been thought to have a "bare lymphocyte syndrome" in which HLA antigens are lacking from circulating lymphocytes (20). Since HLA related antigens have been shown to be acquired during intrathymic ontogeny, it is likely that this syndrome is associated with the SCID patients who have circulating stage I thymocytes (21).

In the DiGeorge syndrome, the presence of mature $T$ cells that have diverged into $\mathrm{T}^{+}{ }^{+}$inducer and the reciprocal $\mathrm{T}^{+}$suppressor/cytotoxic cells, is consistent with the view that these patients have a small thymic rudiment (22). The deficiency of $\mathrm{T}^{+}$cells may correlate with the relative inadequacy of the thymic microenvironment and the observation in the murine systems that suppressor populations are short-lived and require rapid renewal from the thymus gland. 
Although most cases of agammaglobulinemia result from B cell abnormalities, prior studies provided clear evidence for a multitude of other etiologies for lateonset agammaglobulinemia in individuals possessing circulating B cells (23-25). In this regard, in vitro studies have indicated that differentiation of $B$ cells to immunoglobulin secreting plasma cells is regulated by $\mathrm{T}$ cells. Specifically, the $\mathrm{T}^{+}$population enhances immunoglobulin production whereas the $\mathrm{T} 5 / \mathrm{T}^{+}$subset can suppress immunoglobulin secretion by B cells in the presence of $\mathrm{T}^{+}$inducer $\mathrm{T}$ cells (6). Perhaps more importantly, the degree of suppression is directly related to the ratio of $\mathrm{T}^{+}$and $\mathrm{T} 5 / 8^{+}$cells. Thus, at a physiologic ratio of $2: 1$, no suppression is observed, while at lower ratios, (i.e., 1:1, 1:2, 1:5), moderate to marked suppression is seen (6). These in vitro results and our present findings suggest that a large number of patients with this disease may have acquired agammaglobulinemia on the basis of an abnormally low ratio of inducer/suppressor $\mathrm{T}$ lymphocytes.

One individual (case 13) was found to have an elevated number of suppressor cells expressing the Ia antigen, indicating in vivo activation (14). A similar activated suppressor population has been seen in patients with acute infectious mononucleosis (26). Thus, viral infection would appear to be capable of activating selectively a suppressor population of cells. This is of interest since acquired agammaglobulinemia has been seen to follow a variety of viral infections including infectious mononucleosis (27). Whether the de novo acquired agammaglobulinemia associated with a normal number of circulating $B$ cells is in some way related to viral disease is yet to be determined.

A novel form of acquired agammaglobulinemia with circulating B cells, characterized by a total absence of the $\mathrm{T}^{+}$inducer population, was defined in case 14 . The etiology of this individual's loss of the T4 subset is unclear since there was no evidence for a circulating autoantibody to inducer lymphocytes. It seems noteworthy that despite the great excess of $\mathrm{T}^{+}$cells in this patient, no functional suppressor activity could be demonstrated. Lacking $\mathrm{T4}^{+}$inducer cells, this individual may not have been able to activate $\mathrm{T}^{+}$suppressor cells. Furthermore, although not found in the present series of patients, it is likely that acquired agammaglobulinemia may be associated with a phenotypically normal number of $\mathrm{T}^{+}$inducer and $\mathrm{T} 5^{+}$ suppressor populations, but which are functionally defective.

The absence of a predominant $T$ cell subset defect in patients with $\mathrm{X}$-linked agammaglobulinemia who lacked circulating surface immunoglobulin bearing cells is consistent with the view that this disease is due to an aberrant differentiation along cells of $B$, rather than $T$ lineage. However, the observation that patients with both decreased as well as increased inducer/suppressor ratios are frequently detected, suggests that the disease is heterogeneous. In this regard, the multiple infections often contracted by these patients may alter their $T$ cell population. Alternatively, the $T$ cell subset abnormalities may be secondary to the $B$ cell defects themselves. In either case, such combined $T$ and $B$ cell abnormalities may serve to propagate the immunodeficiency state or to thwart their repair with healthy donor cells (28). The use of monoclonal antibodies to precisely define the abnormalities of lymphoid cells will undoubtedly help to unravel this complexity. It is also likely in the future that even more sophisticated probes will be able to define defects in class specific helper or suppressor $\mathrm{T}$ cells resulting in selective isotype deficiencies.

\section{ACKNOWLEDGMENTS}

The authors wish to thank Dr. James F. Jones, Department of Pediatrics, University of Arizona, and Dr. Claude Griselli, Hôpital des Enfants Malades, Paris, France for providing lymphocytes from several patients for analysis.

This work was supported by National Institutes of Health grants AI 12069, CA 19589, CA 06516, CA 16673, RR 128, and a grant from the March of Dimes (1-608).

\section{REFERENCES}

1. Reinherz, E. L., and S. F. Schlossman. 1980. Current concepts in immunology. Regulation of the immune response-inducer and suppressor $\mathrm{T}$ lymphocyte subsets in human beings. $N$. Engl. J. Med. 303: 370-373.

2. Cantor, H., and E. A. Boyse. 1977. Regulation of cellular and humoral immune responses by $\mathrm{T}$ cell subclasses. Cold Spring Harbor Symp. Quant. Biol. 41: 23-32.

3. Reinherz, E. L., P. C. Kung, G. Goldstein, and S. F. Schlossman. 1979. Separation of functional subsets of human $\mathrm{T}$ cells by a monoclonal antibody. Proc. Natl. Acad. Sci. U. S. A. 76: 4061-4065.

4. Reinherz, E. L., P. C. Kung, G. Goldstein, and S. F. Schlossman. 1979. Further characterization of the human inducer $\mathrm{T}$ cell subset defined by monoclonal antibody. J. Immunol. 123: 2894-2896.

5. Reinherz, E. L., P. C. Kung, J. M. Breard, G. Goldstein, and S. F. Schlossman. 1980. T cell requirements for generation of helper function in man: analysis of the subsets involved. J. Immunol. 124: 1883-1887.

6. Reinherz, E. L., C. Morimoto, A. C. Penta, and S. F. Schlossman. 1980. Regulation of B cell immunoglobulin secretion by functional subsets of $\mathrm{T}$ lymphocytes in man. Eur. J. Immunol. 10: 570-572.

7. Reinherz, E. L., P. C. Kung, G. Goldstein, and S. F. Schlossman. 1980. A monoclonal antibody reactive with the human cytotoxic/suppressor $\mathrm{T}$ cell subset previously defined by a heteroantiserum termed $\mathbf{T H}_{2}$. J. Immunol. 124: 1301-1307.

8. Reinherz, E. L., P. C. Kung, G. Goldstein, R. H. Levey, and S. F. Schlossman. 1980. Discrete stages of intrathymic differentiation: Analysis of normal thymocytes and leukemic lymphoblasts of T lineage. Proc. Natl. Acad. Sci. U. S. A. 77: 1588-1592.

9. Reinherz, E. L., P. C. Kung, G. Goldstein, and S. F. Schlossman. 1979. A monoclonal antibody with selective reactivity with functionally mature human thymocytes and all peripheral human $\mathrm{T}$ cells. J. Immunol. 123: 1312-1317. 
10. Waldmann, T. A., S. Broder, C. K. Goldman, S. Marshall, and L. Muul. 1980. Suppressor cells in common variable immunodeficiency. Inserm (Inst. Natl. Sante Rech. Med.) Symposium. 16: 119-128.

11. Moretta, L., M. C. Mingau, S. L. Webb, E. R. Pearl, P. M. Lydyard, C. E. Grossi, A. R. Lawton, and M. D. Cooper. 1977. Imbalances in $T$ cell subpopulations associated with immunodeficiency and autoimmune syndromes. Eur. J. Immunol. 7: 969-700.

12. Reinherz, E. L., A. Rubinstein, R. S. Geha, A. J. Strelkauskas, F. S. Rosen and S. F. Schlossman. 1979. Abnormalities of immunoregulatory $\mathrm{T}$ cells in disorders of immune function. N. Engl. J. Med. 301: 1018-1022.

13. W.H.O. Scientific Group on Immunodeficiency. 1978. Immunodeficiency. WHO, Geneva. 1-80.

14. Reinherz, E. L., P. C. Kung, J. M. Pesando, J. Ritz, G. Goldstein and S. F. Schlossman. 1979. Ia determinants on human $\mathrm{T}$ cell subsets as defined by monoclonal antibody. Activation stimuli required for expression. J. Exp. Med. 150: 1472-1482.

15. Kearney, J. T., M. D. Cooper, and A. R. Lawton. 1976. B cell differentiation induced by lipopolysaccaride IV development of immunoglobulin class restriction in precursors of IgG synthesizing cells. J. Immunol. 117: 1567.

16. Pahwa, R. N., S. G. Pahwa, and R. A. Good. 1979. T lymphocyte differentiation in severe combined immunodeficiency. Defects of stem cells. J. Clin. Invest. 64: 1632-1641.

17. Lischner, H. W., H. H. Punnett, and A. M. DiGeorge. 1967. Lymphocytes in congenital absence of the thymus. Nature (Lond.). 214: 580.

18. DiGeorge, A. M. 1968. Congenital absence of the thymus and its immunological consequences. Concurrence with congenital hypoparathyroidism. In Birth Defects. Original articles series. 4: 110-123.

19. Kretschmer, R., B. Say, D. Brown, and F. S. Rosen. 1968.
Congenital aplasia of the thymus gland (DiGeorge's syndrome). N. Engl. J. Med. 279: 1295-1301.

20. Touraine, J. L., H. Betuel, G. Souillet, and M. Jeune. 1978. Combined immunodeficiency disease associated with absence of cell surface HLA-A and B antigens. J. Pediatr. 93: 47-51.

21. Bhan, A. K., E. L. Reinherz, S. Poppema, R. T. McCluskey, and S. F. Schlossman. 1980. Location of T cell and MHC antigens in the human thymus. J. Exp. Med. 152: 771-782.

22. Lischner, H. W. 1972. DiGeorge syndrome(s). J. Pediatr. 81: 1042.

23. Waldmann, T. A., S. Broder, R. M. Blaese, M. Durm, M. Blackman and W. Strober. 1979. Role of suppressor T cells in pathogenesis of common variable hypoglobulinemia. Lancet. II: 609-613.

24. Siegal, F. P., M. Siegal, and R. A. Good. 1976. Suppression of B cell differentiation by leukocytes from hypogammaglobulinemic patients. J. Clin. Invest. 58: 109-122.

25. Geha, R. S., E. Schneeberger, E. Merler, and F. S. Rosen 1974. Heterogeneity of "acquired" or common variable agammaglobulinemia. N. Engl. J. Med. 291: 1-6.

26. Reinherz, E. L., C. O'Brien, P. Rosenthal, and S. F. Schlossman. 1980. The cellular basis for viral-induced immunodeficiency: analysis by monoclonal antibodies. J. Immunol. 125: 1269-1274.

27. Provisor, A. J., J. J. Iacuone, R. R. Chilcote, R. G. Neiburger, F. C. Crussi, and R. Bacher. 1975. Acquired agammaglobulinemia after life threatening illness with clinical and laboratory features of infectious mononucleosis in three related male children. N. Engl. J. Med. 293: 62

28. Cruchard, A., C. Laperrousa, and R. Megeuand. 1968. Agammaglobulinemia in monozygous twins: therapeutic Prospects. In Birth Defects. (Original article series.) 4: 315-327. 